Gut, 1989, 30, 950-954

\title{
Human serum transglutaminase and coeliac disease: correlation between serum and mucosal activity in an experimental model of rat small bowel enteropathy
}

\author{
G D'ARGENIO, I SORRENTINI, C CIACCI, S SPAGNUOLO, \\ R VENTRIGLIA, A DE CHIARA, AND G MAZZACCA
}

From the Cattedra di Gastroenterologia, Astanteria Chirurgica, Anatomia Patologica, II Facolta' di Medicina, Universita' di Napoli, Italy

SUMmaRy Transglutaminase (TG) activity is increased in the mucosa of patients with coeliac disease. Among 18 patients with untreated coeliac disease we have found a significant decrease $(p<0 \cdot 001)$ in serum levels of TG activity $(0 \cdot 72(0 \cdot 23) \mathrm{mU} / \mathrm{ml})$. There was no significant differences between 16 treated coeliacs $(1 \cdot 24(0 \cdot 28) \mathrm{mU} / \mathrm{ml})$ and 30 normal controls $(1 \cdot 63(0 \cdot 42) \mathrm{mU} / \mathrm{ml})$. To evaluate the connection between serum and mucosal TG activity we used the experimental model of methotrexate induced acute hypoplastic enteropathy in the rat. Transglutaminase activity was unchanged in serum and mucosa 24 and 48 hours after MTX administration, but increased in mucosa $(2.606(0.95) v$ basal $0.207(0 \cdot 026) \mathrm{mU} / \mathrm{mg}$ protein, $\mathrm{p}<0.001)$ and significantly decreased in serum at 72 hours $(2.08(0.38) v$ basal $5.56(1.50) \mathrm{mU} / \mathrm{ml}, \mathrm{p}<0.001)$ during intestinal cell proliferation. Activity of the enzyme in the mucosa and serum returned to baseline levels within 120 hours. This experimental animal model helps to explain the data of TG activity in human intestinal mucosa and serum reported in this study. Results are mean (SD).

Transglutaminase (TG) activity is present in a number of tissues ${ }^{1-3}$ including large and small intestine.$^{45}$ In serum, TG activity is the result of the presence of coagulation factor XIIIa. ${ }^{6}$ Bruce and colleagues recently showed in in vitro experiments that gliadin is an excellent substrate for TG and found an increased enzyme activity in mucosal biopsies from patients with untreated and treated coeliac disease. On the basis of these findings they postulated a new pathogenetic hypothesis for coeliac disease: intestinal TG activity may be important in gliadin binding to tissues and thus in the pathogenesis of coeliac disease.

Stimulated by their report, we have studied TG activity in serum and mucosa of coeliac patients in both remission and acute phases. To further evaluate the relationship between changes in TG activity in serum $v$ intestinal tissues during atrophic damage of

Address for correspondence: Dr G D'Argenio, Cattedra di Gastroenterologia, 2a Facolta' di Medicina, via Pansini 5, 80131 Napoli, Italy.

Accepted for publication 14 November 1988. small bowel mucosa, we also studied TG activity modifications at those sites during acute enteropathy induced in rats by administration of methotrexate (MTX) which produces mucosal damage ${ }^{8}$ resembling that of mucosal atrophy in coeliacs.

\section{Methods}

PATIENTS

Three groups of subjects were enrolled in the study: 18 patients with coeliac disease in relapse, 16 coeliacs in complete remission after at least one year of strict gluten free diet, and 30 healthy volunteers as control subjects. Most of patients in relapse showed anaemia, hypoalbuminaemia, and hyposideraemia, all of them showed alteration of the common malabsorption tests (decreased xylosuria, raised faecal fat excretion). In all patients biopsy specimens were obtained by upper endoscopy. Coeliacs in relapse showed total or subtotal villous atrophy. In patients in remission the malabsorption tests were normal and 
villous atrophy was completely or partially reversed even if a slight lymphoplasmacellular infiltrate was sometimes present.

Transglutaminase activity on jejunal biopsies from 14 control subjects, referred to endoscopy for functional diseases, six coeliacs in relapse and seven in remission was also assayed. Venous blood samples were collected after an overnight fast and serum was stored at $-20^{\circ} \mathrm{C}$. Assays were performed within two months. Transglutaminase activity was tested as described below.

\section{ANIMALS}

Five groups of seven adult male Wistar rats weighing 200-300 g were injected through the femoral vein with a single dose of MTX $(30 \mathrm{mg} / \mathrm{kg}$ body weight in $0.5 \mathrm{ml}$ saline). The rats were killed under ether anaesthesia at $24,48,72,96$, and 120 hours after drug administration. A group of seven rats injected with saline alone and killed at $24 \mathrm{~h}$ was used as control. All the animals were fed ad libitum and had unlimited access to tap water. Blood samples were collected immediately after killing and the serum was stored at $-20^{\circ} \mathrm{C}$ until the assay was performed. The intestine was removed from the ligament of Treitz to the ileocaecal valve and a central piece was used for histopathological evaluation. The two remaining pieces of intestine were opened longitudinally, the whole mucosa was gently scraped on ice and a $10 \%$ homogenate in $50 \mathrm{mM}$ mannitol $0.2 \mathrm{mM}$ Tris $\mathrm{pH} \mathrm{7.1}$ buffer was prepared and stored at $-20^{\circ} \mathrm{C}$ until the time of assay.

\section{ENZYME DETERMINATIONS}

Transglutaminase was assayed by a modification ${ }^{7}$ of the Lorand method ${ }^{9}$ with 14C-putrescine and dimethylcasein used as substrates. Serum enzyme was determined with an incubation time of 20 minutes at $37^{\circ} \mathrm{C}$ and $\mathrm{pH} 9$.

The incubation time and the optimal $\mathrm{pH}$ were chosen after preliminary study indicating the enzyme's activity as a linear function of the time up to 50 minutes and its progressive increase from $\mathrm{pH} 6.5$ to $\mathrm{pH} 9 \cdot 0$.

A $30 \mu \mathrm{l}$ serum sample or tissue homogenate was added to $45 \mu \mathrm{l}$ of reaction mixture containing a final concentration of $0.25 \mathrm{mmol} / \mathrm{l}$ 14C-putrescine (Amersham, England), $50 \mathrm{mmol} / 1$ dithiothreitol, 10 $\mathrm{mmol} / \mathrm{l} \mathrm{CaCl} 2$ and $4 \%(\mathrm{~W} / \mathrm{V})$ dimethylcasein in Tris $\mathrm{HCl}$ buffer $(50 \mathrm{mmol} / \mathrm{l}) \mathrm{pH} 9.0$ with $0.1 \%$ Triton $\mathrm{X}$ 100 . The reaction mixture was incubated and shaken at $37^{\circ} \mathrm{C}$ for 20 minutes. $20 \mu \mathrm{l}$ were spotted onto Whatman $3 \mathrm{MM}$ filter paper rounds $(\varnothing 2 \mathrm{~cm})$ and immediately plunged into $10 \%$ ice cold trichloroacetic acid (TCA) for 15 minutes.

Two consecutive 15 min washings were performed in $5 \%$ ice cold TCA followed by a brief washing in ethanol/acetone and acetone. Sucrase activity in homogenised mucosa was performed by the Dahlqvist method. ${ }^{10}$ Total proteins were detected by the Lowry method."

\section{SMALL INTESTINE MICROSCOPY}

Specimens were immersed in Clark's fixative $(75 \%$ ethyl alcohol, 25\% glacial acetic acid). After 24 hours at room temperature the specimens were transferred to $75 \%$ ethyl alcohol in water and stored. Villous height, crypt depth and mitoses/crypt ratio of rat intestine tissues, were evaluated by light microscopy with a calibrated micrometer according to Ferguson and coworkers. ${ }^{12}$

\section{STATISTICAL ANALYSIS}

Analyses were performed using the Student's $t$ test for unpaired data. Results are presented as mean (SD).

\section{Results}

COELIAC PATIENTS AND CONTROLS

Table 1 includes details of transglutaminase activity in serum of control subjects, coeliacs in relapse and coeliacs in remission. Transglutaminase activity in serum of untreated coelicas $(0 \cdot 72(0 \cdot 23) \mathrm{mU} / \mathrm{ml})$ was significantly lower than that of control subjects $(1.63$ $(0.42) \mathrm{mU} / \mathrm{ml})(\mathrm{p}<0.001)$. In coeliac patients in remission TG was reduced but not significantly $(1 \cdot 24$ $(0 \cdot 28) \mathrm{mU} / \mathrm{ml})$. In a smaller number of subjects upper endoscopy biopsy specimens were also obtained which were assayed for TG activity. Our results, confirming Bruce and colleagues report, showed a significant $(p<0.001)$ increase of enzyme activity in coeliacs in relapse compared with control subjects $(4.39(0.75)$ and $1.61(0.53)$. In coeliacs in remission, TG mucosal activity was also increased $(2.54(0.90))$ although the difference was less significant, $\mathrm{p}<0.02$.

\section{ANIMALS}

\section{General response}

Within $24 \mathrm{~h}$ of injection, MTX-treated rats decreased their food intake. By $96 \mathrm{~h}$, this had returned to normal. Diarrhoea was noted at 24 and $48 \mathrm{~h}$.

\section{Small Intestine Microscopy}

Light microscopy showed some mucosal damage in the intestines of rats killed $24 \mathrm{~h}$ after MTX injection.

Villi were slightly shorter than normal, with vacuoles present in goblet cells; crypt mitoses were absent and crypt microabscesses appeared. Specimens from rats killed at $48 \mathrm{~h}$ showed severe acute mucosal damage characterised by short villi, 
Table 1 Transglutaminase (TG) activity in serum and jejunal mucosa of normal and coeliac patients

\begin{tabular}{|c|c|c|c|}
\hline & $\begin{array}{l}\text { Control } \\
\text { subjects } \\
M(S D)\end{array}$ & $\begin{array}{l}\text { Coeliacs in } \\
\text { relapse } \\
M(S D)\end{array}$ & $\begin{array}{l}\text { Coeliacs in } \\
\text { remission } \\
M(S D)\end{array}$ \\
\hline $\begin{array}{l}\text { Serum TG } \\
(\mathrm{mU} / \mathrm{ml}) \S\end{array}$ & $\begin{array}{c}1.63(0 \cdot 42) \\
(n=30)\end{array}$ & $\begin{array}{c}0.72(0 \cdot 23)^{*} \\
(n=18)\end{array}$ & $\begin{array}{c}1 \cdot 24(0 \cdot 28) \dagger \\
(n=16)\end{array}$ \\
\hline $\begin{array}{l}\text { Mucosal TG } \\
\text { (mU/mg protein)§ }\end{array}$ & $\begin{array}{c}1.61(0.53) \\
(n=14)\end{array}$ & $\begin{array}{c}4.39(0.75)^{*} \\
(n=6)\end{array}$ & $\begin{array}{c}2.54(0.90) \ddagger \\
(n=7)\end{array}$ \\
\hline
\end{tabular}

${ }^{*} \mathrm{p}<0.001 ; \uparrow \mathrm{NS} ; \ddagger \mathrm{p}<0.02 ; \S 1 \mathrm{mU}=1 \mathrm{nmol}$ of putrescine into acceptor protein at $37^{\circ} \mathrm{C}, \mathrm{pH}=9$.

vacuoles, loss of differentiation of apical cells and no crypt mitoses. Crypt microabscesses were more accentuated than those observed at $24 \mathrm{~h}$. In the mucosa of rats killed at $72 \mathrm{~h}$, similar but less severe structural damage was present and there were a few mitoses in the crypts with enlarged cells at the crypt bases and there were no crypt microabscesses. At 96 $h$ epithelium had begun to recover: villus height was almost normal, goblet cells were present at the apex of the villi and crypts were deeper than normal.

At $120 \mathrm{~h}$ the general architecture, crypts, villi and number of mitoses had returned to normal, showing no differences between experimental and control groups. Results of the morphological examination are summarised in Table 2.

ENZYME ACTIVITY

Basal mucosal TG activity was $0 \cdot 207(0 \cdot 026) \mathrm{mU} / \mathrm{mg}$ protein. Transglutaminase activity remained substantially unchanged up to $48 \mathrm{~h}$, at which point it increased greatly until $72 \mathrm{~h}(2.606(0.95) \mathrm{mU} / \mathrm{mg}$ protein, $\mathrm{p}<0.001)$, and at $96 \mathrm{~h}$ TG activity had returned to basal values.

Basal serum TG activity was $5.56(1.50) \mathrm{mU} / \mathrm{ml}$. There were no significant changes at 24 and $48 \mathrm{~h}$. After a significant decrease registered at 72 h $(2.00$

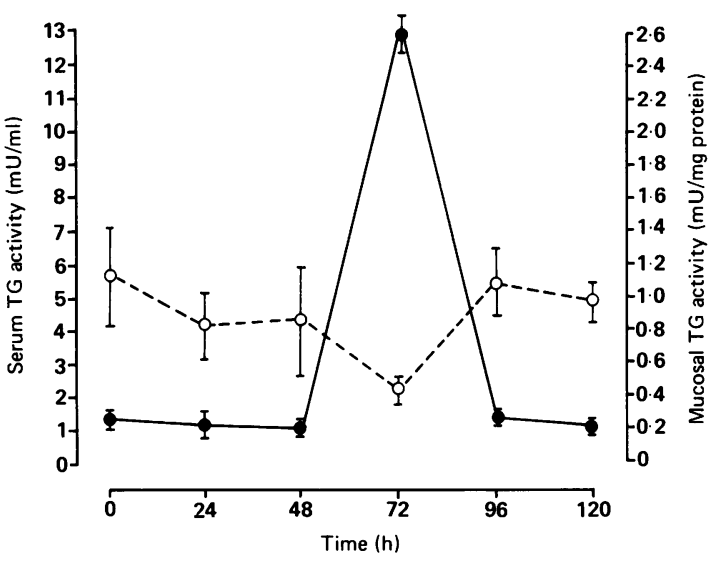

Fig. 1 Serum (broken line) and intestinal transglutaminase activity $\mathrm{v}$ time after methotrexate injection in rats.

$(0.38) \mathrm{mU} / \mathrm{ml}, \mathrm{p}<0.001)$, it had returned to basal value at $96 \mathrm{~h}$ (Fig. 1 ).

Figure 2 shows the comparison between mucosal sucrase and TG activity over the same period. The lowest level of sucrase activity was observed at $72 \mathrm{~h}$, simultaneously with the peak increment of mucosal TG activity; the decrease was significant compared to baseline (40 (10) $v 201(18) \mathrm{U} / \mathrm{g}$ protein, $\mathrm{p}<0 \cdot 001)$.

\section{Discussion}

Our data show for the first time the relationship between serum transglutaminase concentrations and coeliac disease activity. Mean serum TG values in coeliac patients on a normal diet, presenting a malabsorption syndrome and a total or subtotal mucosal atrophy at histological examination, were significantly lower than those of normal controls and coeliac patients in remission. Serum TG activity changes observed in untreated coeliac patients

Table 2 Structure of small bowel mucosa in five groups of rats injected with methotrexate (MTX) $30 \mathrm{mg} / \mathrm{kg}$ and untreated rats (control); mean (SD)

\begin{tabular}{|c|c|c|c|c|c|c|}
\hline \multirow[b]{2}{*}{$n$} & \multirow[b]{2}{*}{$\begin{array}{l}\text { Control } \\
\text { (7) }\end{array}$} & \multicolumn{5}{|c|}{ Time after injection of $M T X$} \\
\hline & & $\begin{array}{l}24 h \\
\text { (7) }\end{array}$ & $\begin{array}{l}48 h \\
\text { (7) }\end{array}$ & $\begin{array}{l}72 h \\
\text { (7) }\end{array}$ & $\begin{array}{l}96 h \\
\text { (7) }\end{array}$ & $\begin{array}{l}120 h \\
\text { (7) }\end{array}$ \\
\hline Villous height $(\mu \mathrm{m})$ & $498(22)$ & $\begin{array}{c}475(18) \\
\text { NS }\end{array}$ & $\begin{array}{l}284(11) \\
p<0.001\end{array}$ & $\begin{aligned} 394 & (23) \\
p & <0.05\end{aligned}$ & $\begin{array}{c}487(18) \\
\text { NS }\end{array}$ & $\begin{array}{c}495(15) \\
\text { NS }\end{array}$ \\
\hline Crypt depth $(\mu \mathrm{m})$ & $180(10)$ & $\begin{array}{c}167(9) \\
\text { NS }\end{array}$ & $\begin{array}{l}160(12) \\
\text { NS }\end{array}$ & $\begin{array}{l}195(7) \\
\text { NS }\end{array}$ & $\begin{array}{l}238(18) \\
p<0.05\end{array}$ & $\begin{array}{l}192(14) \\
\text { NS }\end{array}$ \\
\hline Mitoses/crypt & $2 \cdot 48(0 \cdot 12)$ & $\begin{array}{l}0 \cdot 12(0.09) \\
\mathrm{p}<0.001\end{array}$ & $\begin{array}{l}1.25(0.80) \\
\mathrm{p}<0.05\end{array}$ & $\begin{array}{l}3.05(0.08) \\
\mathrm{p}<0.05\end{array}$ & $\begin{array}{l}2 \cdot 55(0 \cdot 18) \\
\text { NS }\end{array}$ & $\begin{array}{l}2 \cdot 60(0 \cdot 20) \\
\text { NS }\end{array}$ \\
\hline Presence of microabscesses & - & + & ++ & - & - & - \\
\hline
\end{tabular}

p: MTX compared with controls. NS: not significant. 


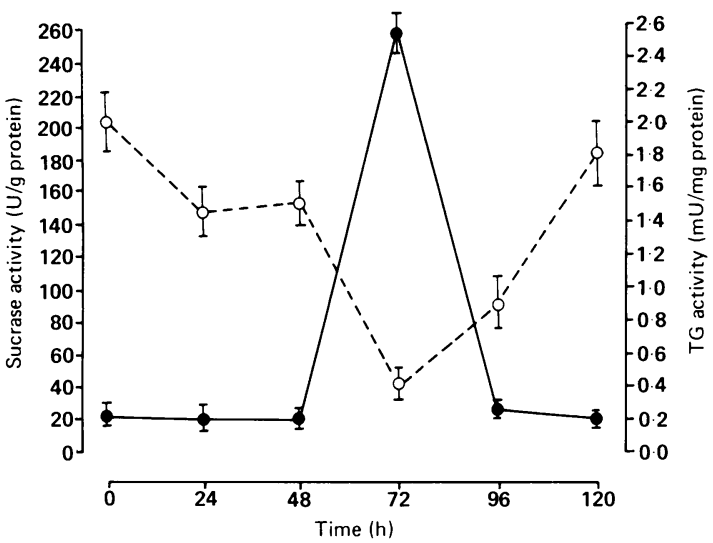

Fig. 2 Mucosal transglutaminase and sucrease (broken line) activities $\mathrm{v}$ time after methotrexate injection in rats.

appeared unrelated to any defect of blood coagulation.

Our results on human jejunal mucosa confirm those reported in literature ${ }^{7}$ of an increased TG activity in coeliacs in relapse.

The acute MTX-induced enteropathy creates an experimental model somewhat resembling coeliac mucosal lesions: superficial atrophy and crypt hyperplasia. ${ }^{1314}$ In our rats with MTX-induced enteropathy, during the proliferative phase $(72 \mathrm{~h}$ following MTX administration), mucosal sucrase activity diminished significantly and returned to basal values when mucosal recovery was complete, indicating the presence of brush border. ${ }^{15}$ The time course analysis of mucosal TG activity during our experiment showed alterations which were opposite to those of the sucrase activity. In fact, at $72 \mathrm{~h}$, an increase in the TG activity was observed. This result contrasts with that previously reported by Patel et al, ${ }^{5}$ who detected a significant reduction of mucosal TG activity during the initial phase of MTX-induced acute atrophy. The discrepancy may be rhe result of different drug dosage, mode of administration, tissue sampling, homogenisation technique and/or different reference parameters. On the other hand our findings on mucosal TG activity during the proliferative phase agree with those on regenerating tissues. ${ }^{16}$ It seems unlikely that the observed TG serum activity reduction was the result of a toxic side effect of MTX administration, because the decrease became evident only after $72 \mathrm{~h}$ when the acute phase of MTX-induced damage had ended.

Similarly, in the coeliac patients in relapse, an inverse relation between serum and intestinal TG changes during the phase of mucosal atrophy and repairing crypt proliferation, was observed in our rats. Whether the phenomenon is caused by exfolia- tion or loss of TG into the gut lumen or to reduced release of intestinal TG into serum, which would be needed locally for crypt hyperproliferation, remains a speculative hypothesis.

In conclusion our results show the existence of a decreased serum concentration of TG related to coeliac disease activity, suggesting that determination of this enzyme in serum of coeliac patients could be useful in monitoring disease remission. Furthermore we have shown an inverse relationship between serum and intestinal TG activity in MTX treated rats.

The Authors are grateful to Professor A Ferguson for reviewing the manuscript, Mss Carla Perrot, Patrizia Ferro and Carla Mautone for nursing care, $\mathrm{Mr}$ Pasquale Esposito for his technical assistance, and Mrs Mary Spears for editing the manuscript for English publication.

\section{References}

1 Folk JE. Transglutaminases. Annu Rev Biochem 1980; 49: 517-31.

2 Birckbichler PJ, Orr JR, Cornway E, Patterson MK. Transglutaminase activity in normal and transformed cells. Cancer Res 1977; 37: 1340-4.

3 Conconi F, Grazi E. Transamidinase of hog kidney. Purification and properties. J Biol Chem 1965; 240: 2461-4.

4 D’Argenio G, Sorrentini I, Ciacci C, Mazzacca G. Transglutaminase activity along rat small bowel and cellular location. Enzyme 1988; 39: 227-30.

5 Patel EK, Bruce SE, Bjarnason I, Peters TJ. Rat gastrointestinal transglutaminase: Demonstration of enzyme activity and cell and tissue distribution. Cell Biochem Funct 1985; 3: 199-203.

6 Fesus L, Metsis ML, Musbek L, Kotelianski VE. Transglutaminase-sensitive glutamine residues of human plasma fibronectin revealed by studying its proteolytic fragments. Eur J Biochem 1986; 154: 371-4.

7 Bruce SE, Bjarnason I, Peters TJ. Human jejunal transglutaminase: demonstration of activity, enzyme kinetics and substrate specificity with special relation to gliadin and celiac disease. Clin Sci 1985; 68: 573-9.

8 Taminiau JAJM, Gall DJ, Hamilton JR. Response of the rat small-intestine epithelium to Methotrexate. Gut 1980; 21 : 486-92.

9 Lorand L, Campbell-Wilkes LK, Cooperstein L. A filter paper assay for transamidating enzyme using radioactive amine substrate. Ann Biochem 1972; 50: 623-31.

10 Dahlquist A. Method of assay of intestinal disaccharidases. Anal Biochem 1964; 7: 18-25.

11 Lowry OH, Rosebrough NJ, Farr AL, Randall RJ. Protein measurement with the folin phenol reagent. J Biol Chem 1951; 193: 265-75.

12 Ferguson A, Sutherland A, McDonald TT, Francis A. Technique for microdissection and measurement in biopsies of human small intestine. J Clin Pathol 1977; 30: 1068-73.

13 Eastwood GL. Gastrointestinal epithelial renewal. 
Gastroenterology 1977; 72: 962-75.

14 Williamson RCN. Intestinal adaptation. $N$ Engl J Med 1978; 298: 1444-50.

15 Schimitz J, Preiser H, Maestracci D, Ghosh BK, Cerda JJ, Crane RK. Purification of the human intestinal brush border membrane. Biochem Biophys Acta 1973; 323: 98-112.

16 Haddox MK, Russell DH. Increased nuclear conjugated polyamines and transglutaminase during liver regeneration. Proc Natl Acad Sci USA 1981; 78: 1712-6. 